\title{
The effects of clam fishing on the properties of surface sediments in the lagoon of Venice, Italy
}

\author{
R.J. Aspden ${ }^{1}$, S. Vardy ${ }^{1}$, R.G. Perkins ${ }^{1}$, I.R. Davidson ${ }^{1}$, R. Bates ${ }^{2}$ and D.M. Paterson ${ }^{1}$ \\ ${ }^{1}$ Sediment Ecology Research Group, Gatty Marine Laboratory, St Andrews University, Fife, KY16 8LB, Scotland, UK \\ ${ }^{2}$ School of Geography and Geosciences, Irvine Building, St Andrews University, Fife, KY16 9AL, Scotland, UK
}

Email for corresponding author: rja4@st-andrews.ac.uk

\begin{abstract}
Harvesting of clams (Tapes philippinarum) has important socio-economic and environmental implications for the Venice lagoon area, Italy. Clam harvesting disrupts the structure of benthic communities but the effects upon sediment stability and surface structure remain unclear. The effect of clam fishing on the sediment properties of the lagoon bed was investigated at two different sites, a heavily fished site (San Angelo) and an infrequently fished site (San Giaccomo). Both sites were assessed for immediate impacts of fishing, using indicators of biogenic sediment stabilisation. Samples were taken at three points along three $100 \mathrm{~m}$ linear transects at each site prior to and post fishing. Paired samples were also taken parallel to each transect at a distance of $5 \mathrm{~m}$, to allow for temporal variation. Sediment stability, measured with a cohesive strength meter $(\mathrm{CSM})$, was significantly higher at the less impacted site $\left(\mathrm{F}_{1,34}=6.23, \mathrm{p}<0.018\right)$, was correlated with indicators of biogenic sediment stabilisation and decreased by approximately $50 \%$ following the trawling event. Concomitant decreases in chlorophyll $a$ ( $\mathrm{chl} a$ ), colloidal-S carbohydrate and dry bulk density were observed on the transect after fishing but not adjacent to the fishing path. At the heavily impacted site, clam fishing by trawling had, in general, no significant effect on the biological and physical properties (although chl $a$ did decrease significantly after fishing). The lack of a significant impact from fishing at the impacted site was attributed to the higher frequency of fishing occurring in this area. Hence, frequent fishing of the lagoon prevents establishment of biotic communities, preventing biostabilisation and thus reduces the stability of the surface sediment.
\end{abstract}

Keywords: clam harvesting, erosion threshold, microphytobenthos, sediment, stability

\section{Introduction}

Venice lagoon, a semi-enclosed body of water with limited freshwater inflows and three links to the northern Adriatic, has an average depth of $1 \mathrm{~m}$ and an area of 55000 ha, making it the widest lagoon area in the Mediterranean. Open water and tidal channels comprise $78 \%$ of the enclosed lagoon area (Ravera, 2000; Sorokin et al., 2002) and the general ecology of the system is balanced between riverine and marine influences. The lagoon plays an important role in the fishery production of the Mediterranean, being a nursery area and feeding ground for many fish exploited commercially. The clam fishery has an annual yield of 50000 tonnes and ancillary fishery businesses employ approximately 2500 people, accounting for an annual turnover of 73 million Euros (Rosetto, 2000).

However, the Venice lagoon is under increasing threat; not only is sediment erosion greater than deposition, causing the lagoon to deepen, but also sea level is rising because of climatic change. As a result, the extreme high tides, the 'aqua alta,' that Venice experiences are becoming increasingly frequent. The sediment dynamics within the lagoon are critical for the ecological status of the system and are controlled mainly by wave energy, river flow and coastal currents. The resistance of the surface sediments to erosion can be affected directly by physical disturbances such as clam harvesting (fishing) and by the constant passage of ships or vapparettos, which reduce the bed shear strength, or indirectly by disturbing or removing biological components, such as the microphytobenthos (MPB) which promote stabilisation.

Little literature is available on the impacts of disturbances such as clam harvesting on soft/muddy sediment habitats. After trawling, Hauton and Paterson (2003) reported a reduction in sediment shear strength, whilst Jennings et al. (2001) found a significant decrease in infaunal and epifaunal biomass. Structures such as sea grass rhizomes and 
polychaete tubes (Fager, 1964; Carey, 1983; Fonseca and Fisher, 1986; Freidrichs, 2000) help to maintain sediment stability and, if removed or (Tolomio et al., 1999; Facca et $a l ., 2002)$ damaged by fishing apparatus, the potential for bed erosion increases. Re-suspension of sediments and subsequent release into the water column of organic material, previously buried, can create an oxygen deficit. Alternatively, sediment re-suspension may increase nutrient levels and so promote phytoplankton blooms (Orth, 1977). Rates of re-colonisation after fishing can vary dramatically depending upon physical factors including the scale of disturbance, sediment type, hydrological flow patterns, storm events and the intrinsic stability of the sediment; it is thought that the period between disturbance events, although site specific, is a key factor in the success of re-colonisation (Spencer et al., 1997; Collie et al., 2000).

Since the Venice lagoon is shallow, benthic macro-algae and microphytobenthos play an important role in the sediment dynamics because of flow manipulation and production of metabolic exudates (Tolomio et al., 1999; Facca et al., 2002). Microphytobenthos comprise diatoms, euglenoids, flagellates and cyanobacteria (Paterson et al., 1998; MacIntyre and Cullen, 1996; Yallop et al., 1994); however, diatoms (Bacillariophyceae) are often the most common representatives (Admiraal, 1984). Diatoms are single celled phototrophic eukaryotic algae and many of the biraphid benthic forms produce extracellular polymeric substances (EPS) as part of their locomotory mechanism (Edgar and Picket-Heaps, 1984). This secretion plays an important role in the mechanical stabilisation of sediments (Holland et al., 1974; Yallop et al., 1994; Austin et al., 1999) by forming an extensive matrix and coating the sediment with organic material, thereby promoting inter-particle binding (Chenu and Jaunet, 1992; Chenu, 1993).

Biostabilisation of the sediment has, therefore, an important effect on the hydromorphology of the Venice lagoon and must be considered within the remit of policies currently under consideration within management plans to reduce the impact of flooding. With high levels of artisanal and commercial clam fishing, the lagoon is an ideal site to examine the effect of shallow water fishing methods on benthic ecosystem function. The aim of this study was, therefore, to determine whether sediment disturbance resulting from clam fishing was associated with decreases in sediment stability and concomitant changes in indicators of biogenic stabilisation. It was hypothesised that, at a site with a low fishing impact, biogenic stabilisation would play a significant role in sediment stabilisation, whereas, at a highly impacted site, sediment stability would be lower because of the frequency of disturbance.

\section{Materials and methods}

\section{STUDY SITES}

Two sites, subject to different frequencies of clam fishing, were selected for study; they were San Giacomo, in the Paludo area, and San Angelo della Polvere (Fig. 1). Historically, the intensity of fishing at San Giacomo is negligible because it is an area of low clam productivity. Average water depth at this site is $1.25 \mathrm{~m}$, requiring the use of a small centre consol vessel, with two additional outboard motors, one suspended from each side of the boat (Fig. 2a). The re-suspended sediment passes through nets placed behind the additional motors to collect the clams. In contrast, San Angelo is a site of high fishing intensity, because of the high yield of clams it sustains. Water depth at this site is typically $2.25 \mathrm{~m}$ and so commercial trawling vessels $(20 \mathrm{~m}$ in length) with larger harvesting mechanisms (cage of $158 \mathrm{~cm}$ $\times 38 \mathrm{~cm}$ ) can be used and are the preferred fishing method (Fig. 2b).

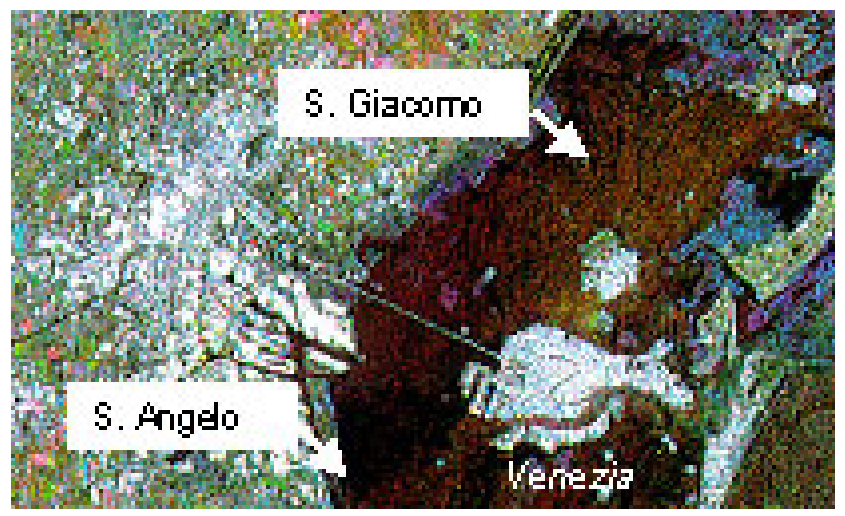

Fig. 1. Aerial photograph showing the positions of San Angelo and San Giacomo within the Lagoon of Venice.

\section{SEDIMENT SAMPLING}

Three transects (100 m long), were designated for fishing or re-suspension by outboard motor (dependent upon water depth) at each study site. Replicate intact sediment cores $(10 \mathrm{~cm}$ internal diameter, $\mathrm{n}=4)$ were obtained by a SCUBA diver, at three points $(25 \mathrm{~m}, 50 \mathrm{~m}$ and $75 \mathrm{~m})$ along each transect line and, additionally, at the same points parallel to, but $5 \mathrm{~m}$ off each transect line. Cores were taken prior to and post clam fishing (or re-suspension methods).

On the boat, immediately after collection, one core from each sample point was used to measure the critical shear stress $\left(\tau_{\text {o,crit, }} \mathrm{Nm}^{-2}\right)$, using a cohesive strength meter (CSM Mk III), an in situ erosion device (Tolhurst et al., 1999). 

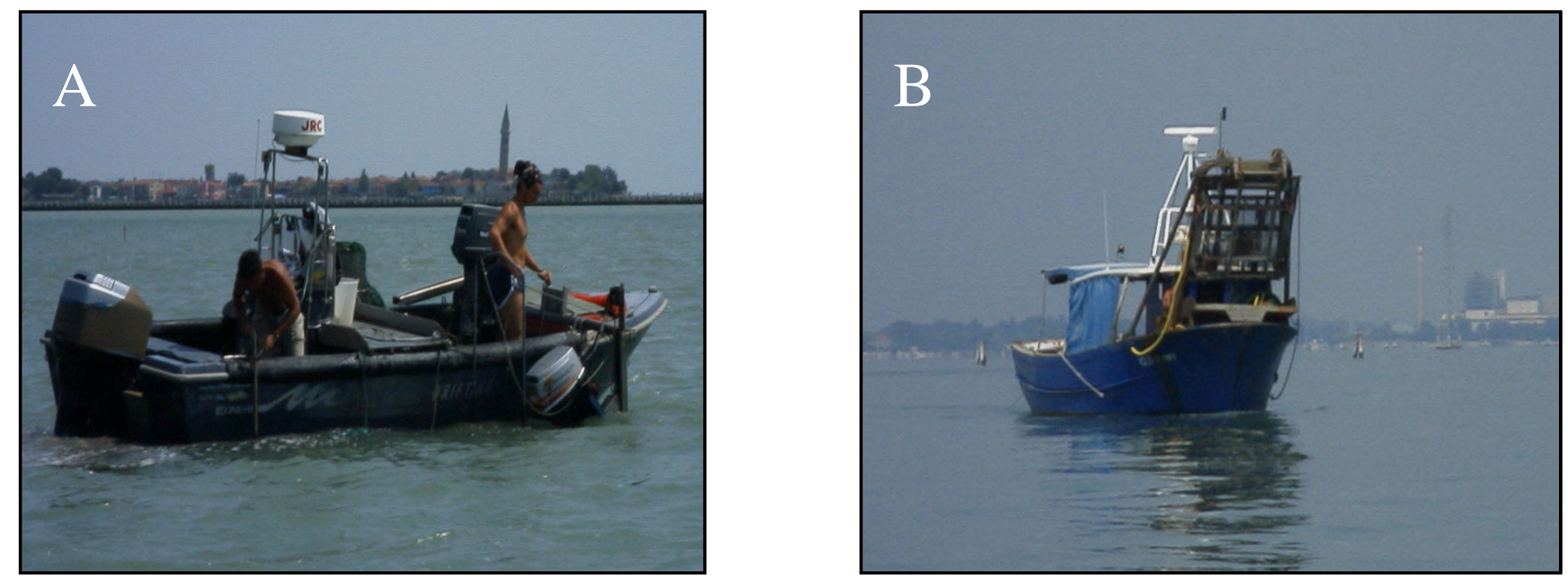

Fig. 2. Water depth at San Giacomo (A) was typically $1.25 \mathrm{~m}$ so small centre consol vessels were used with additional outboard motors suspended over the sides of the boat. Water depth at San Angelo (B) was typically $2.25 \mathrm{~m}$ allowing the use of small commercial trawling vessels to harvest clams.

The surface algal biomass (Chlorophyll $a(\operatorname{chl} a)$ fluorescence) was measured using a pulse amplitude modulated (PAM) Diving-PAM fluorimeter (Walz, Effeltrich, Germany). The minimum fluorescence yield, obtained after 15 minutes dark adaptation $\left(F_{o}{ }^{15}\right)$, has been used as a proxy for microphytobenthic surface biomass (Barranguet and Kromkamp, 2000; Perkins et al., 2001; Honeywill et al., 2002). When this signal was below detection, despite setting the gain and measuring beam intensity of the Diving-PAM to maximum, the yield prior to dark adaptation was monitored as an indication of the presence of surface algal biomass (i.e. a qualitative, but not quantitative measurement). Thus one measurement of critical erosion threshold (and presence of algal biomass) was made at three sample points along each of the three transects, both prior to and post fishing, and on and off each transect, resulting in a total of 36 measurements.

The remaining three replicate cores were used for analysis of biogenic sediment stabilisation. The top $3-5 \mathrm{~mm}$ of the sediment surface from each core was removed by contact freezing with liquid nitrogen-cooled metal, using the contact core method (Honeywill, 2001) and stored in liquid nitrogen until lyophilisation prior to further sediment analysis. Thus, three samples were taken from three sample points along each of the three transects, both prior to and post fishing, and on and off each transect, resulting in a total of 108 samples.

Visual impacts of clam fishing were obtained using images of the seabed taken prior to and post trawling, using Imagenix 885 side scan sonar, with a frequency of $675 \mathrm{kHz}$ and range set at $100 \mathrm{~m}$.

\section{SEDIMENT ANALYSIS}

The variables used as proxies for biogenic sediment stability (Black and Paterson, 1997; Consalvey, 2002; Paterson, 1997) were chl $a$ content, colloidal-S carbohydrate content, dry bulk density and organic carbon content. Chl $a$ and pheo phorbides (assumed pigment breakdown products) were extracted using demethylformamide (DMF) and quantified using high performance liquid chromatography (HPLC). Extracts were filtered through a $0.2 \mathrm{~mm}$ nylon filter. The HPLC system consisted of a quaternary high-pressure pump system (Perkin Elmer 410), an autosampler (Waters WISP 417 ) and a diode array detector (Waters 910). Samples were kept in the dark at $4{ }^{\circ} \mathrm{C}$ in the autosampler, and a $70 \mathrm{ml}$ injection of each sample was made with an addition of $30 \mathrm{ml}$ of deionised water. A C18-nucleosil column was used with a flow rate of $1 \mathrm{mlmin}^{-1}$ and a tertiary gradient solvent system (Table 1). The three solvent systems used were: A) $2000 \mathrm{ml}$ methanol, $500 \mathrm{ml}$ water, $3.75 \mathrm{~g}$ of tetrabutylammonium acetate and $19.25 \mathrm{~g}$ ammonium acetate; B) $2250 \mathrm{ml}$ methanol and $250 \mathrm{ml}$ acetone; and C) $435 \mathrm{ml}$ propanol and $565 \mathrm{ml}$ methanol (Table 1.). The diode array detector was set to collect data at a wavelength of $430 \mathrm{~nm}$. As an indicator of the 'health' of the surface sediments prior to trawling, ratios of chl $a$ to pheophorbides were calculated.

Colloidal-S carbohydrates were extracted using the methods of Underwood et al. (1995) and Smith and Underwood (1998). Colloidal-S content was defined as the fraction extracted from lyophilised sediment by saline water (salinity 20 ) at $20^{\circ} \mathrm{C}$, and quantified using the Dubois assay (Dubois et al., 1956) as ppm glucose equivalents (GE), using a D-glucose standard curve. Absorbance was measured 
Table 1 . The tertiary gradient system used during HPLC pigment analysis. For solvent content details $(\% \mathrm{~A}, \% \mathrm{~B}, \% \mathrm{C})$, see text.

\begin{tabular}{lccrrrr}
\hline Step & $\begin{array}{c}\text { Time } \\
\text { (min) }\end{array}$ & $\begin{array}{l}\text { Time } \\
\text { (cumulative) }\end{array}$ & $\% A$ & $\% B$ & $\% C$ & Curve \\
\hline 0 & 0 & 0 & 100 & 0 & 0 & \\
1 & 5 & 5 & 50 & 50 & 0 & 1 \\
2 & 5 & 10 & 50 & 50 & 0 & \\
3 & 5 & 15 & 0 & 100 & 0 & 1 \\
4 & 10 & 25 & 0 & 100 & 0 & \\
5 & 2 & 27 & 100 & 0 & 0 & 1 \\
6 & 2 & 29 & 0 & 0 & 100 & 1 \\
7 & 3 & 32 & 0 & 0 & 100 & \\
8 & 3 & 35 & 100 & 0 & 0 & 1 \\
9 & 5 & 40 & 100 & 0 & 0 & \\
\hline
\end{tabular}

(Cecil 3000 spectrophotometer) against a reagent blank at $485 \mathrm{~nm}$.

Sediment dry bulk density was calculated by measuring the loss of weight from a wet sediment sample (of known weight and volume), after lyophilisation for 24 hours. Organic carbon content was measured as ash-free dry weight, calculated as the loss in weight after a known weight of sediment was ignited in a muffle furnace at $450^{\circ} \mathrm{C}$ for 4 hours. Sediment grain size was determined using a Beckman Coulter LS 230 Particle Size Analyser. Grain sizes were separated into four groups (Wentworth, 1922): $<63 \mu \mathrm{m}$ (silt/ clay), $63 \mu \mathrm{m}-125 \mu \mathrm{m}$ (very fine sand), $125 \mu \mathrm{m}-500 \mu \mathrm{m}$ (fine/ medium sand), and $>500 \mu \mathrm{m}$ (coarse sand).

Microphytobenthic assemblages were examined using light microscopy. Counts of 300 individuals were made, unless the number of individuals was low, in which case timed searches of 2 hours were made. Microphytobenthos present at the sediment surface were collected over one hour using the lens tissue method (Moss and Evans, 1966) and preserved in glutaraldehyde prior to permanent slide preparation by acid-cleaning the samples to remove organic matter (Simonsen, 1974).

\section{STATISTICAL ANALYSIS}

Chl $a$ content, colloidal-S carbohydrate content, dry bulk density, and organic carbon content were tested for differences prior to and post trawling, using one-way ANOVA. Post hoc analysis used the Tukey test to identify the cause of variation at a significance level of $p<0.05$. The critical erosion threshold data did not meet the criteria of ANOVA and were tested using the non-parametric KruskalWallis test. Results were considered significant at $p<0.05$. PCORDWIN $^{\mathrm{TM}}$ (v 3.01 - MJM Software) was used for reciprocal averaging to examine significant patterns within the microphytobenthic community data. Shannon-Weaver indices were applied to microphytobenthos cell count data, to compare diversity of species within sites.

\section{Results}

\section{COMPARISON OF SITES}

\section{Microphytobenthic biomass}

$\mathrm{Chl} a$ content decreased significantly after fishing on the test transects at both sites (San Angelo: $\mathrm{F}_{3,104}=8.468, \mathrm{p}<$ 0.001, ; San Giacomo: $\left.F_{3,103}=28.139, p<0.001\right)$ but not on the control sites parallel to but $5 \mathrm{~m}$ off the transects (Figs. 3-4). The Chl $a$ : pheophorbide ratio decreased after the fishing event at San Giacomo (Fig. 5). San Giacamo also had a higher chl $a$ : pheophorbide ratio than San Angelo.

Despite using the most sensitive settings, fluorescence yields were below the minimum level acceptable for photophysiological measurements (130 relative units, Honeywill et al., 2002); both prior to and post dark adaptation fluorescence was below 20 relative units, preventing qualitative measurement of surface algal biomass.

\section{Sediment critical erosion threshold}

$\tau_{c}$ did not differ significantly on or off the transects prior to fishing at either sampling site, so data were pooled for statistical analysis. San Giacomo sediment had a higher erosion threshold than San Angelo prior to fishing, but this reduced to a similar level of stability after passage of the

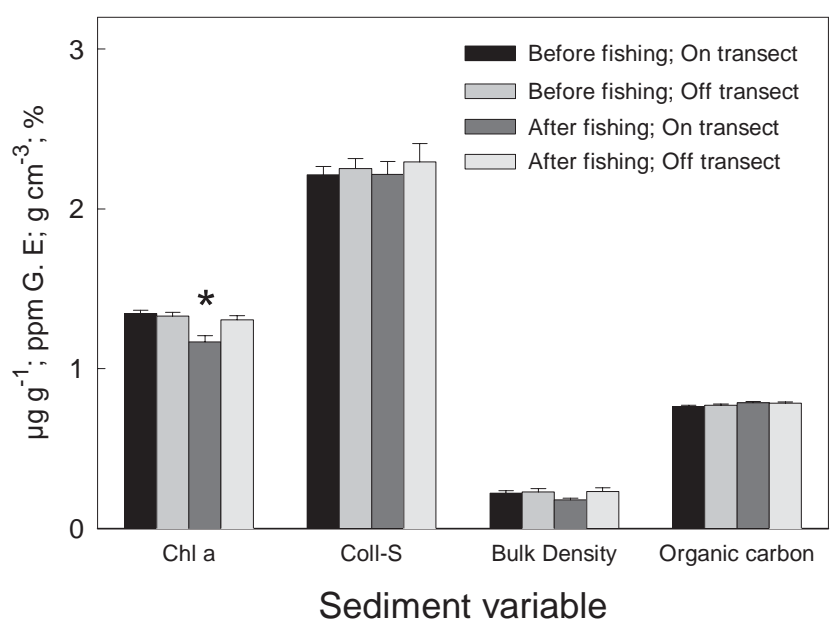

Fig. 3. San Angelo: chl a $\left(\mu \mathrm{g} \mathrm{m}^{-2}\right)$, colloidal-S carbohydrate (ppm glucose equivalents), bulk density $\left(\mathrm{g} \mathrm{cm}^{-3}\right)$ and organic carbon content (\%) of lyophilised sediment from San Angelo. Significant differences $(*=p<0.05)$, and mean ( \pm s.e.), are indicated; $n=24$ -27 . 


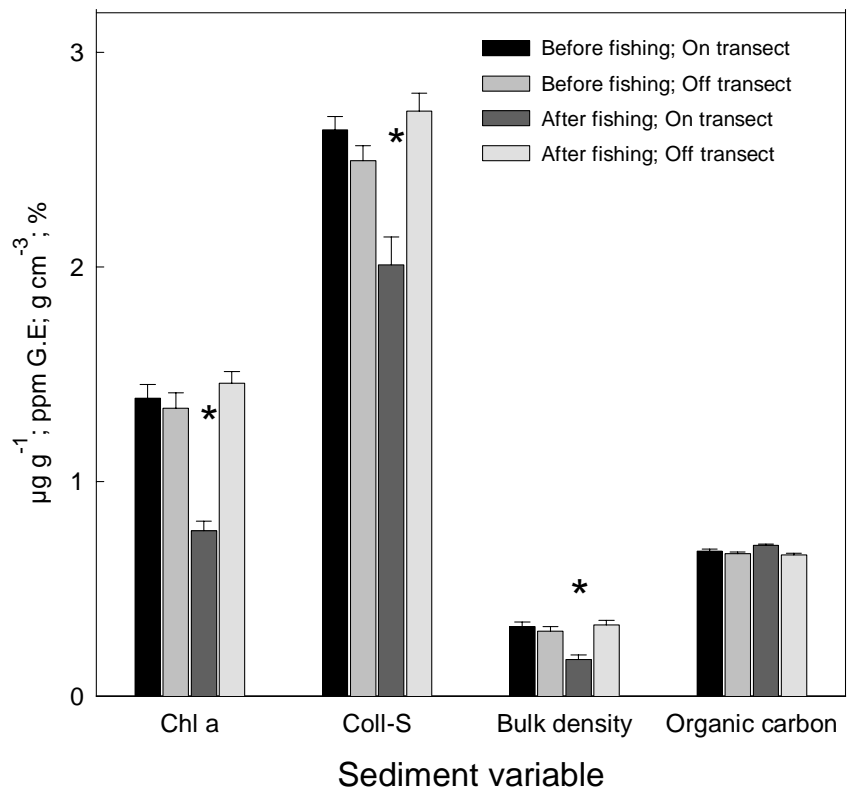

Fig. 4. San Giacomo: chl a $\left(\mu \mathrm{g} \mathrm{m}^{-2}\right)$, colloidal-S carbohydrate (ppm glucose equivalents), bulk density $\left(\mathrm{g} \mathrm{cm}^{-3}\right)$ and organic carbon content (\%) of lyophilised sediment from San Giacomo. * = significant difference at $p<0.05$. Mean \pm s.e., $n=24-27$.

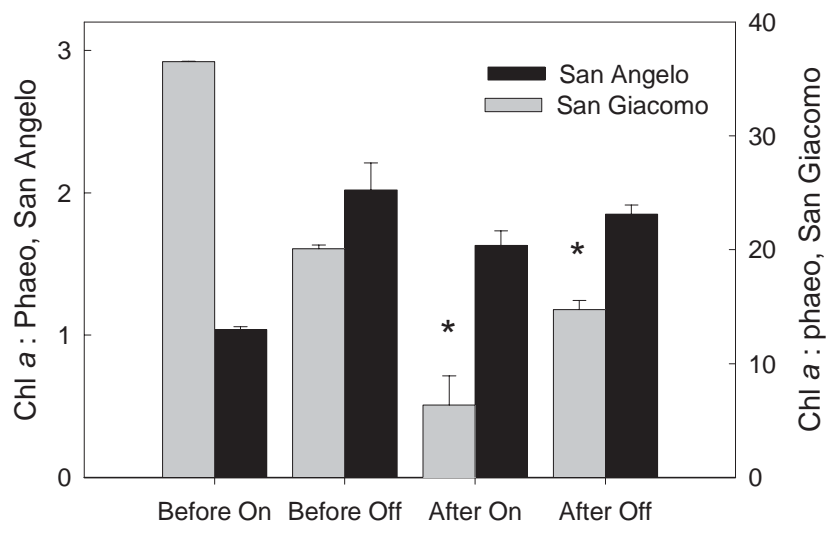

Sampling period (before/after fishing) and transect (on/off)

Fig. 5. Chl a to phaeophorbide ratios in sediment samples from San Angelo and San Giacomo. Mean \pm s.e., $n=16-25$ ).

small fishing boat and outboard motors (Fig. 6). There was less variation in sediment stability after trawling at San Angelo than at San Giacomo.

\section{COMPARISON WITHIN SITES}

San Angelo (high impact site, fished by mechanical harvesting apparatus)

Silt/clay ( $\pm 63 \mathrm{um}$ ) represented over $70 \%$ of the total sediment volume. $5-10 \%$ of the total volume exceeded a

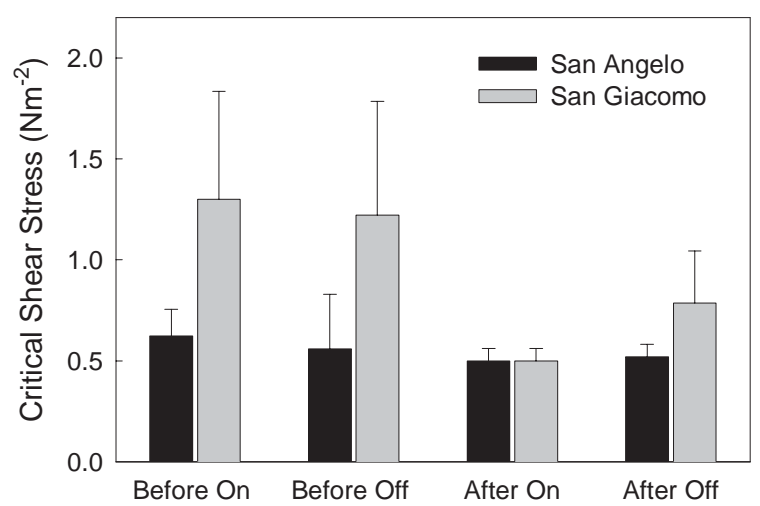

Sampling period (before/after fishing) and transect (on/off)

Fig. 6. Critical erosion threshold, $\ddot{A}_{c}\left(\mathrm{Nm}^{-2}\right)$, for intact sediment cores at San Angelo and San Giacomo. Mean \pm s.e., $n=9$.

particle size of $500 \mu \mathrm{m}$ and was composed largely of shell fragments, probably indicative of the previous extent of clam fishing in this area (Fig. 7).

Chl $a$ content declined significantly on and off the transects, with the sediment on the transects decreasing significantly after fishing $\left(\mathrm{F}_{3,104}=8.468, \mathrm{p}<0.001\right.$; Fig. 3). All other measurements (carbohydrate content, dry bulk density and organic carbon content) were unaffected by

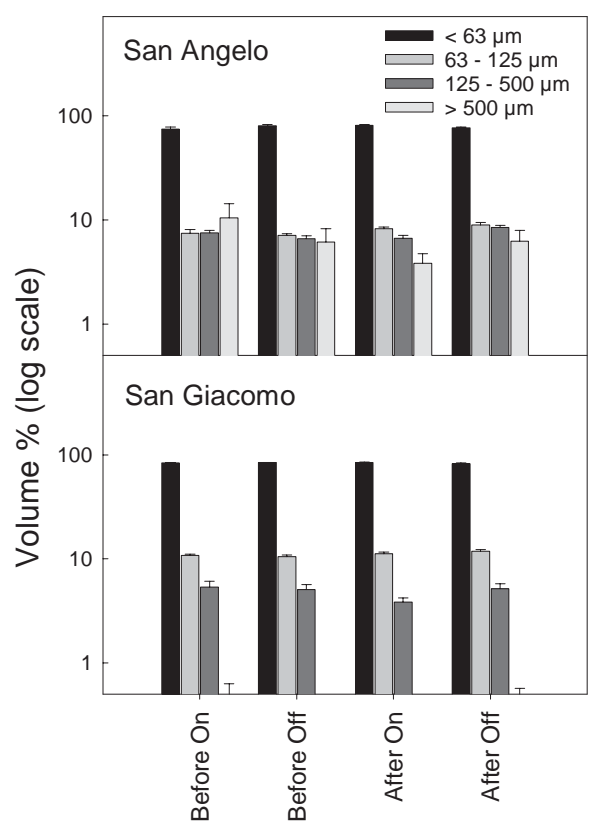

Sampling period (before/after fishing) and transect (on/off)

Fig. 7. Percentage distributions for size classes of grain size volume for lyophilised sediment samples from San Angelo and San Giacomo (mean \pm s.e., $n=24$ - 27). Size classes: < $63 \mu \mathrm{m}$ (silt / clay), $63 \mu \mathrm{m}-$ $125 \mu \mathrm{m}$ (very fine sand), $125 \mu \mathrm{m}-500 \mu \mathrm{m}$ (fine/ medium sand), and $>500 \mu \mathrm{m}$ (coarse sand). 


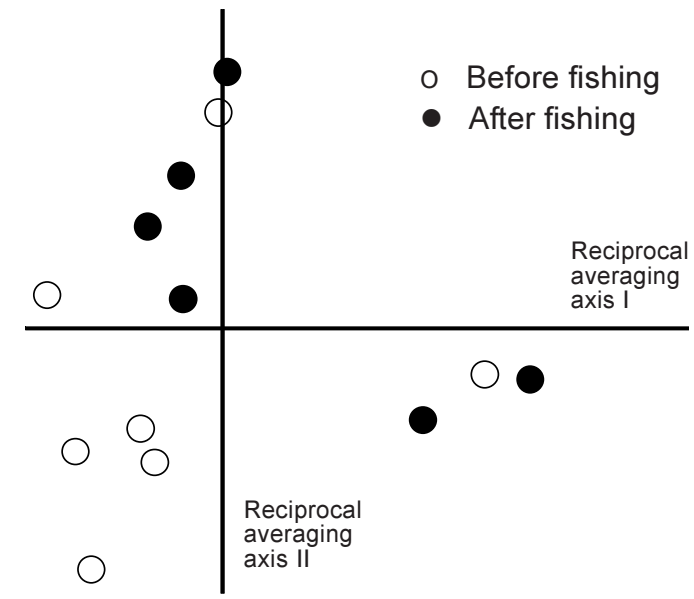

Fig. 8. Reciprocal average plot of the microphytobenthic community assemblage at San Angelo. Using the correspondence of time (prior to and post fishing event) and dominant species (>1\%), no variation was observed.

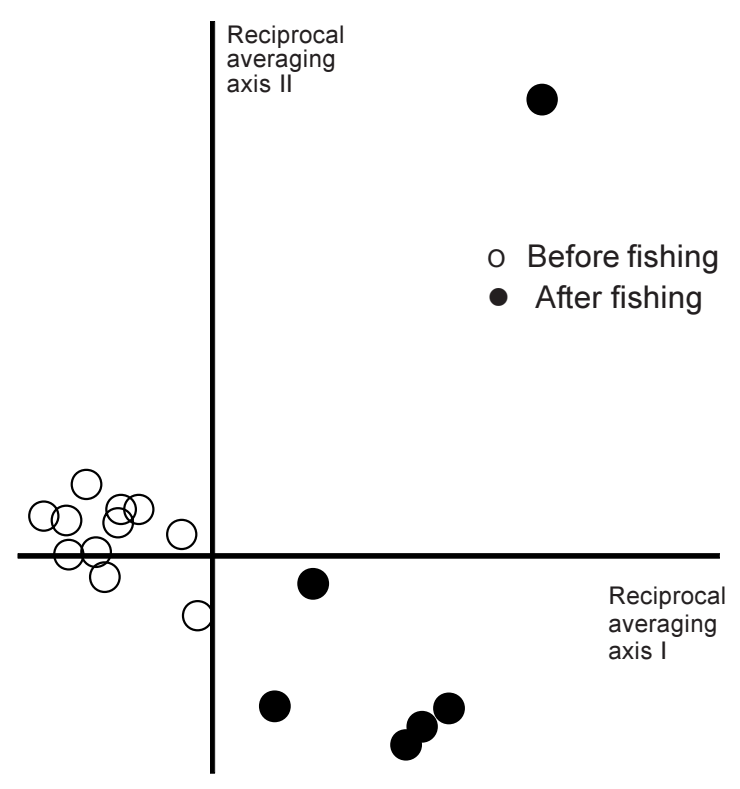

Fig. 9. Reciprocal average plot of the microphytobenthic assemblage at San Giacomo. Using the correspondence of time (prior to and post fishing event) and dominant species $(>1 \%)$, variations between samples prior to fishing and post fishing event were observed.

fishing. The diversity of benthic algal assemblages varied from 1.82 to 1.78 (Shannon-Weaver Index), before and after fishing respectively, suggesting a minor, possibly negligible, effect of fishing on immediate community structure. The dominant diatom taxa found on the sediments were Navicula cincta, Nitzchia dissipata, Nitzchia constricta, Coconeis scutellum, and Amphora sp. The correspondence of sample ordinations were compared (Fig. 8), and microphytobenthic assemblage composition did not differ before and after fishing. $\tau_{c}$ showed no variation after fishing (Fig. 6). Side scan sonar images showed a high level of disturbance prior to fishing activity (Fig 10a) and, after fishing, most of the previous features had been replaced (Fig.10b).

San Giacomo (low impact site, fished by re-suspension) Silt/clay ( $\pm 63 \mathrm{um}$ ) represented over $80 \%$ of the sediment by volume at San Giacomo. The largest size class $(>500 \mu \mathrm{m})$ occurred as a much lower proportion of the total sediment volume compared to sediment at San Angelo, suggesting a relatively finer sediment matrix and a lack of shell fragments (Fig. 7).

Colloidal-S carbohydrate content decreased significantly after fishing $\left(\mathrm{F}_{3,101}=12.748, \mathrm{p}<0.001\right)$ but only on the fishing transects and not off transect (Fig. 4). No significant temporal differences occurred in the content of organic carbon (Fig. 4).

The sediment dry bulk density was significantly lower after fishing on the fished transect $\left(\mathrm{F}_{3,102}=12.070, \mathrm{p}<0.001\right)$ but not adjacent to it (Fig. 4).

The dominant diatom taxa found were Navicula cincta, Nitzchia dissipata, Nitzchia constricta, Nitzchia frustulum Nitzchia dubiiformis, Coconeis scutellum, Amphora sp, and Gyrosigma acuminatum. The diversity of the assemblage was higher than at San Angelo with a range of 1.83 to 1.98 prior to and post fishing respectively. The correspondences of sample ordinations show that the microphytobenthic community composition before fishing differed from that after fishing. However, the overall diversity of the assemblages was unaffected (Fig. 9).

Despite a decrease, after fishing, in values of the indicators of biogenic stabilisation (chlorophyll $a$, colloidal-S carbohydrate, dry bulk density and organic carbon content), there was no statistically significant decrease in the critical erosion threshold (Fig. 6), although a 50\% reduction did occur $(p=0.05)$.

Side scan sonar images showed a homogenous surface prior to fishing (Fig.10c). However, once the vessel had passed along the transect, a distinct fishing track caused by the outboard motor was evident (Fig. 10d).

\section{Discussion}

The main result of this study of clam fishing intensity upon sediment stability in the Venice lagoon was that high frequency of fishing by conventional trawling prevents establishment of a benthic biotic community, in turn reducing to an undetectable level any biostabilisation of the sediment. In particular, at a highly impacted site (San Angelo), establishment of the microphytobenthos was 


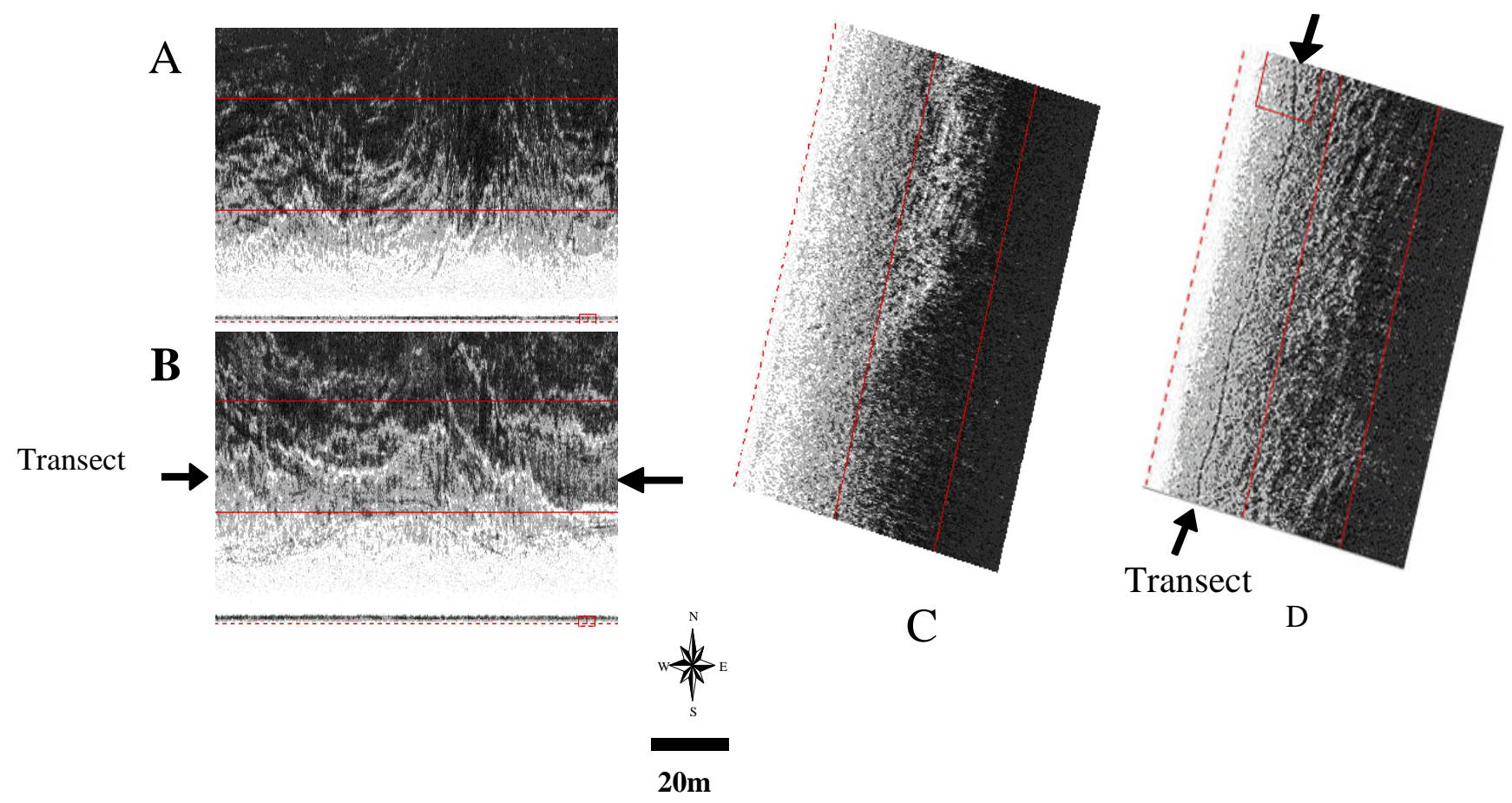

Fig. 10. Side scan sonar images of the same area of sea bed taken at San Angelo prior to (A) and post (B) fishing event, and at San Giacomo prior to (C) and post (D) fishing event, aligned to a north bearing. Note the homogenous nature of the sediment at San Giacomo prior to fishing, compared with the sediment surface at San Angelo. A furrow caused by the outboard motor can be seen clearly after the re-suspension of sediments at San Giacomo.

impeded such that biostabilisation through algal biofilm growth and associated extracellular polymer production did not occur. In comparison, at a low impact site (San Giacomo), some biostabilisation was observed, which was quickly reduced by a single fishing event using an outboard motor to re-suspend the sediment. Biogenic indicators of biostabilisation were all significantly lower at San Angelo than at San Giacomo, indicating a lower potential for biostabilisation at the former site. Thus, when fished, San Angelo showed little change in sediment stability or indices of biostabilisation, as there was little stability or sediment biota to have an impact upon. In contrast, a single fishing pass had detrimental effect at the less impacted site, San Giacomo, where establishment of benthic biota resulted form less frequent fishing. Indeed, fishing in San Giacomo has been negligible although, in the absence of quantitative data on fishing efforts, this cannot be stated for certain and so the site is referred to as a low impact site.

Fishing has a large impact upon the sediments at San Angelo and, therefore, subsequent single fishing events have very little effect, due to the heterogeneity of the area, whereas at San Giacomo a single fishing event had a greater influence on the properties of the sediment surface. A high frequency of fishing disturbance prevents sediment consolidation, the succession of biological communities and the development of stable benthic assemblages. This hypothesis is supported by the side scan sonar images, which also confirm that, before the clam fishing study, San Angelo was more heavily fished than San Giacomo (Fig. 10 a, c). The lack of a distinct track after fishing at San Angelo (Fig. 10b) suggests the sediments were affected differently from those at San Giacomo, either due to the fishing mechanism being used or to the homogeneity of the sediments prior to fishing. However, to determine which factor is causal, an area of the lagoon would have to be cordoned off from fishing access and left to recover fully from any prior fishing activities before measurements could be taken. Nevertheless, the high level of disturbance prior to fishing at San Angelo is strong circumstantial evidence that, at this site, fishing frequency rather than fishing methodology was responsible for the difference.

At San Angelo, the only factor that changed significantly post fishing was the sediment chl a content. Microphytobenthos present on the surface were either dispersed or buried by fishing. Otter trawling, also known as dragging, is one of the most commonly used fishing techniques, during which a large net is dragged along the sediment surface behind a towing vessel. Otter trawling creates a disturbance zone up to $120-250 \mathrm{~m}$ wide (Schwinghamer et al., 1998) but, in the present study, the 
disturbance was less because of the smaller scale of the equipment used. Any effects seen off transect $(5 \mathrm{~m}$ from the trawling path) after fishing would have been due to the disturbance of sediment from the transect and the subsequent spread of re-suspended sediment. The sites adjacent to the transect were mostly unaffected showing the limited impact of the individual dredge lines. In comparison, the results obtained from San Giacomo indicated that the re-suspension of sediment using outboard motors had a major effect on the site in terms of the biological and physical indicators of stabilisation measured. This effect may be more pronounced, as this site is fished for clams less commonly so that benthic assemblages have had more time to develop, allowing biogenic stabilisation of the surface layers to take place (Rhoads et al., 1978). Homogenisation of sediments occurs after fishing due to the destruction of structures such as burrows and mounds. In turn, this decreases the amount of re-suspended sediment within the water column (Pilskaln et al., 1998; Watling and Norse, 1998).

Jennings et al. (2001) found that bivalve harvesting decreased infaunal and epifaunal biomass, although the biomass of polychaetes was unaffected. This indicated that the life strategies of different infauna affect their ability to survive periodic disturbance, suggesting that frequent fishing will select for specific life strategies and perhaps functional groups. Clam fishing, therefore, is likely to have a significant effect on ecosystem function and turnover within the system (Emmerson et al., 2001). This hypothesis can be tested readily within a system such as the Venice lagoon. Both direct and indirect factors may be influential. Defew et al. (2002) showed that Nereis diversicolor increased sediment stability but Arenicola marina decreased the stability of surrounding sediments. These differences could be due to many site-specific factors, including bioturbation effects, sediment type (e.g. grain size), drainage of sediments, burrow formation and grazing pressure upon microphytobenthic biofilms. Problems of using chl $a$ : pigment ratios include deposit feeding, grazing pressures, bacterial breakdown and redistribution of pigments due to disturbance events. These factors must be considered when using the ratio to indicate the health of a system. For example, Lucas and Holligan (1999) showed that grazing had a large effect upon pheophorbide measurements, although Ford and Honeywill (2002) reported that pheophorbide should not be used as a marker of macrofaunal grazing intensity. Due to the very low biomass of macrofauna in the Venice lagoon sediments (authors' personal observation), chl $a$ : pheophorbide ratios were used in this study as an indirect measure of system health with respect to chl $a$ degradation.

A change in community structure or removal of epifauna will affect the microphytobenthos present. This is important since sediment stability is affected by microphytobenthic biomass and associated sediment polymer content (Dade et al., 1990; Underwood and Paterson, 1993; Taylor and Paterson, 1998; Tolhurst, 1999). Consalvey et al. (2002) reported that an increase in sub-tidal sediment stability was positively correlated with microphytobenthic biofilm growth. The presence of microphytobenthos at San Giacomo was noted to change before and after the fishing event, but not at San Angelo. This may have been due to the difference in historical disturbance frequency. Microphytobenthic biofilms present at San Angelo may have become disturbed, re-suspended and dispersed during fishing activities. In addition, the high frequency of fishing may not allow sufficient time for biofilms to recolonise within sediments. At present, there is very little information on the rate of biofilm formation under sub-tidal conditions and this is worth further investigation. Regular fishing disturbs the sediment bed by increasing the turbidity of the water column, which will also have an adverse effect on light penetration and conditions for biofilm development. Thus, a negative feedback could occur, such that high fishing frequency prevents establishment of a benthic algal community, which increases water column turbidity through increased sediment re-suspension, which in turn reduces light penetration and inhibits benthic algal growth.

At San Giacomo the decrease in biogenic indicators of sediment stabilisation suggested that a greater period of time between fishing events could allow a biofilm to form and biostabilise the lagoon sediments, supporting the hypothesis that a greater biogenic stabilisation was occurring at the less disturbed site. Auster (1998) suggested a threshold of disturbance beyond which significant damage to the habitat results. This study indicates that this threshold has not been reached at San Giacomo whereas it has been exceeded, at San Angelo. A crucial question for the management of the lagoon is the critical time between fishing events at a particular site. The period required for this recovery is likely to be site-specific dependant upon factors such as sediment type, hydrography, flow patterns and colonisation of macrofauna and, although data are limited, relevant literature is available (Spencer et al., 1997; Collie et al., 2000). Future studies should include the establishment of areas protected from seabed disturbance by clam fishing for varying time periods to allow them to revert to a natural disturbance frequency, based on episodic storm and flow events, as representative control sites.

This study on clam fishing impacts suggests that frequent fishing within the Venice lagoon reduces the stability of the surface sediments. However, the difficulty of finding an undisturbed site for true control comparisons and the natural 
complexity of the benthic sea habitat make quantifying the effects of disturbance far from simple. This study has illustrated the importance of determining the effects of fishing methods on soft-bottomed systems, in which frequency of sediment disturbance is of great importance with respect to time to allow establishment of benthic biotic communities, which can aid sediment stability.

\section{Acknowledgements}

The work was carried out in collaboration with Consorzio Venezia Nuova, THETIS - Technological Centre of the Venice Arsenale, and S.E.L.C - Società per l'Ecologia delle Lagune e delle Coste.RJA was funded by the EU TIDE award (EVK-CT-2001-00064) and by funding from the University of St Andrews, Scotland. The input of two anonymous referees also helped improve this paper.

\section{References}

Admiraal, W., 1984. The Ecology of Estuarine SedimentInhabiting Diatoms. Prog. Phycol. Res., 3, 269-322.

Auster, P.J., 1998. A conceptual model of the impacts of fishing gear on the integrity of fish habitats. Conserv. Biol., 12, 15231739.

Austin, I., Andersen, T.J. and Edelvang, K., 1999. The influence of benthic diatoms and invertebrates on the erodability of an intertidal mudflat, the Danish Wadden Sea. Estuar. Coast. Shelf Sci., 49, 99-111.

Barranguet, C. and Kromkamp, J., 2000. Estimating primary production rates from photosynthetic electron transport in estuarine microphytobenthos. Mar. Ecol.-Prog. Ser., 204, 3954.

Black, K.S. and Paterson, D.M., 1997. Measurement of the erosion potential of cohesive, marine sediments: a review of current in situ technology. J. Mar. Envir. Eng., 4, 43-84.

Carey, D.A., 1983. Particle resuspension in the benthic boundary layer induced by flow around polychete tubes. Can. J. Fisheries Aquat. Sci., 40, 301-308.

Chenu, C., 1993. Clay polysaccharide or sand polysaccharide associations as models for the interface between microorganisms and soil - water related properties and microstructure. Geoderma, 56, 143-156.

Chenu, C. and Jaunet, A.M., 1992. Cryoscanning electronmicroscopy of microbial extracellular polysaccharides and their association with minerals. Scanning, 14, 360-364.

Collie J.S., Hall S.J., Kaiser M.J. and Poiner I.R., 2000. A quantitative analysis of fishing impacts on shelf-sea benthos. $J$. Anim. Ecol., 69, 785-798.

Consalvey, M., 2002. The structure and function of microphytobenthic biofilms. PhD Thesis, University of St Andrews, UK. 69-72.

Dade, W.B., Davis. J.D., Nichols, P.D., Nowell, A.R.M., Thistle, D., Trexler, M.B. and White, D.C., 1990. Effects of bacterial exopolymer adhesion on the entrainments of sand. Geomicrobiol. J., 8, 1-16.

Defew, E.C., Tolhurst, T.J. and Paterson., 2002. Site-specific features influence sediment stability of intertidal flats. Hydrol. Earth Syst. Sci., 6, 971-982.
Dubois, M., Giles, K.A., Hamilton, J.K., Rebers, P.A. and Smith, F., 1956. Colometric assay for the determination of sugars and related substances. Anal. Chem., 28, 350-356.

Eaton, J.W., and Moss, B., 1966. The estimation of number and pigment content in epipelic algal populations. Limnol. Oceanogr., 11, 584-595.

Edgar, L.A. and Picket-Heaps, J.D., 1984. Diatom locomotion. Prog. Phycol. Res., 3, 47-88.

Emmerson, M., Solan, M., Emes, C., Paterson, D.M. and Raffaelli, D., 2001. Idiosyncratic effects of species diversity on ecosystem function. Nature, 411, 73-77.

Facca, C., Sfriso, A. and Socal, G., 2002. Temporal and spatial distribution of diatoms in the surface sediments of the Venice Lagoon. Bot. Mar., 45, 170-183.

Fager, E.W., 1964. Marine Sediments: Effects of a tube-building polychete. Science, 143, 356-359.

Fonseca, M.S. and Fisher, J.S., 1986. A comparison of canopy friction and sediment movement between four species of seagrass with reference to their ecology and restoration. Mar. Ecol.-Prog. Ser., 29, 15-22.

Ford, R.B. and Honeywill, C., 2002. Grazing on intertidal microphytobenthos by macrofauna: is pheophorbide a a useful marker? Mar. Ecol.-Prog. Ser., 229, 33-42.

Friedrichs, M., Graf, G. and Springer, B., 2000. Skimming flow induced over a simulated polychete tube lawn at low population densities. Mar. Ecol. Prog.-Ser., 192, 219-228.

Hauton, C. and Paterson, D.M., 2003. A novel shear vane used to determine the evolution of hydraulic dredge tracks in sub-tidal marine sediments. Estuar. Coast. Shelf Sci., 56, 1-8.

Holland, A.F., Zingmark, R.G. and Dean, J.M., 1974. Quantitative evidence concerning the stabiliza-196.

Honeywill, C., 2001. In situ analysis of the biomass and distribution of microphytobenthos. PhD Thesis, University of St Andrews, UK. 22.

Honeywill, C., Paterson, D.M. and Hagerthy, S.E., 2002. Instant determination of microphytobenthic biomass using fluorescence. Eur. J. Phycol., 37, 1-8.

Jennings, S., Pinnegar, J.K., Polunin, N.V.C. and Warr, K.J., 2001. Impacts of trawling disturbance on the trophic structure of benthic invertebrate communities. Mar. Ecol.-Prog. Ser., 213, $127-142$.

Lucas, C.H. and Holligan, P.M., 1999. Nature and ecological implications of algal pigment diversity on the Molenplat tidal flat (Westerschelde estuary, SW Netherlands). Mar. Ecol.-Prog. Ser., 180, 51-64.

MacIntyre, H.L. and Cullen, J.J., 1996. Primary production in suspended and benthic microalgae in a turbid estuary: time scales of variability in San Antonio Bay, Texas. Mar. Ecol.-Prog. Ser., 145, 245-268.

Orth, R.J., 1977. The importance of sediment stability in seagrass communities. In: Ecology of Marine Benthos, B.C. Coull (Ed.). Univ. of South Carolina Press, Columbia, USA. 281-300.

Paterson, D.M., 1997. Biological Mediation of Sediment Erodability: Ecology and Physical Dynamics. In: Cohesive Sediments, N. Burt, R. Parker and J. Watts, (Eds.) Wiley, Chichester, UK. 213-215.

Paterson, D.M., Wiltshire, K.H., Miles, A., Blackburn, J., Davidson, I., Yates, M.G., McGrorty, S. and Eastwood, J.A., 1998. Microbiological mediation of spectral reflectance from intertidal cohesive sediments. Limnol. Oceanogr., 43, 12071221.

Perkins, R.G., Underwood, G.J.C., Brotas, V., Jesus, B., Ribeiro, L. and Snow, G. 2001. In situ microphytobenthic primary production during low tide emersion in the Tagus estuary, Portugal: production rates, carbon partitioning and vertical migration. Mar. Ecol.-Prog. Ser., 223, 101-112. 
Pilskaln, C.H., Churchill, J.H. and Mayer, L.M., 1998. Resuspension of Sediment by Bottom Trawling in the Gulf of Maine and Potential Geochemical Consequences. Conserv. Biol., 12, 1523-1739.

Ravera, O., 2000. The Lagoon of Venice: the result of both natural factors and human influence. J. Limnol., 1, 19-30.

Rhoads, D.C., McCall, P.L. and Yingst, J.Y., 1978. Production and disturbance on the estuarine seafloor. Amer. Sci., 66, 57586.

Rossetto, L., http://oregonstate.edu/dept/IIFET/2000/abstracts/ rossetto.html

Schwinghamer, P., Gordon, D.C., Rowell, T.W., Prena, J., Mckeown, D.L., Sonnichsen, G. and Guign, J.Y., 1998. Effects of experimental otter trawling on surficial sediment properties of a sandy-bottom ecosystem on the Grand Banks of Newfoundland. Conserv. Biol., 12, 152--1739.

Simonsen, R., 1974. The diatom plankton of the Indian Ocean expedition of R/V Meteor 1964-5. Meteor Forsch-Ergrbnisse Reihe D., 19, 1-107.

Smith, D.J. and Underwood, G.J.C. Exopolymer production by intertidal epipelic diatoms. Limnol. Oceanogr., 43, 1578-1591.

Sorokin, P.Yu., Sorokin, Yu.I., Zakuskina, O.Yu. and Ravagnan, G.-P., 2002. On the changing ecology of Venice lagoon. Hydrobiologia, 487, 1-18.

Spencer, B.E., Kaiser, M.J., and Edwards, D. B., 1997. Ecological effects of intertidal Manila clam cultivation: observations at the end of the cultivation phase. J. Appl. Ecol., 34, 444-453.

Taylor, I.S. and Paterson, D.M., 1998. Microspatial variation in carbohydrate concentrations with depth in the upper millimetres of intertidal cohesive sediments. Estuar. Coast. Shelf Sci., 46, $359-370$.
Tolhurst, T.J., 1999. Microbial mediation of intertidal sediment stability. PhD Thesis, University of St Andrews, UK. 11.

Tolhurst, T.J., Black, K.S., Shayler, S.A., Mather, S., Black, I., Baker, K. and Paterson, D.M., 1999. Measuring the in situ erosion shear stress of intertidal sediments with the cohesive strength meter (CSM). Estuar. Coast. Shelf Sci., 49, 281-294.

Tolomio, C., Moschin, E., Moro, I. and Andreoli, C., 1999. The phytoplankton of Venice Lagoon. 1. Northern and southern basins (April 1988 - March 1989). Vie Milieu, 49, 33-44.

Underwood, G.J.C. and Paterson, D.M., 1993. Seasonal changes in diatom biomass, sediment stability and biogenic stabilization in the Severn estuary. J. Mar. Biol. Assn. UK., 73, 871-887.

Underwood, G.J.C., Paterson, D.M. and Parkes R.J., 1995. The measurement of microbial carbohydrate exopolymers from intertidal sediments. Limnol. Oceanogr, 40, 124-1253.

Watling, L. and Norse, E.A., 1998. Disturbance of the seabed by mobile fishing gear: A comparison to forest clear cutting. Conserv. Biol., 12, 1180-1197.

Wentworth, C. K., 1922. A scale of grade and class terms for clastic sediments. J. Geol., 30, 377-392.

Yallop, M.L., de Winder, B., Paterson, D.M. and Stal, L.J., 1994. Comparative structure, primary production and biogenic stabilisation of cohesive and non cohesive marine sediments inhabited by microphytobenthos. Estuar. Coast. Shelf Sci., 39, $565-582$. 